\title{
TITLE:
}

\section{Foucauldian theory and the making of the Japanese sporting body}

$\operatorname{AUTHOR}(\mathrm{S})$ :

Miller, Aaron L.

\section{CITATION:}

Miller, Aaron L.. Foucauldian theory and the making of the Japanese sporting body. Contemporary Japan 2015, 27(1): 13-31

\section{ISSUE DATE:}

2015

URL:

http://hdl.handle.net/2433/235680

\section{RIGHT:}

(C) 2015 Aaron L. Miller. This work is licensed under the Creative Commons Attribution-NonCommercial-NoDerivs 3.0 License. 


\title{
Open Access
}

\section{Aaron L. Miller}

\section{Foucauldian theory and the making of the Japanese sporting body}

\begin{abstract}
International sporting competitions, such as the upcoming 2020 Tokyo Olympic Games, adhere to a nationalistic and triumphalist paradigm in which strength, victories, and medals are judged more important than anything else. Within this paradigm, what matters most is which sporting body can subdue another. National sporting consciousnesses often reflect this paradigm, and the case of Japan offers no exception. How do international power relations within such paradigms shape sporting bodies, national sports consciousnesses, and our knowledge of them? To answer this question, this paper applies the theory of Michel Foucault to a historical study of Japanese sports. By applying Foucault's theory of power, especially his ideas of "bio-power" and the "productive" nature of "power relations," we can better interpret historical shifts in the way Japanese have perceived their sporting bodies over time, especially the view that the Japanese sporting bodies are unique but inferior when compared with non-Japanese sporting bodies. International power relations and perceptions of cultural inferiority weigh heavy on Japanese sporting bodies. They produce certain behaviors, such as the action of toeing the line for one's team, especially when that team is the nation, and certain discourses, such as the narrative that Japanese sporting bodies must train together to best play together.
\end{abstract}

Keywords: sporting body, nationalism, body nation, bio-power

Aaron L. Miller: Kyoto University, e-mail: Amiller333@yahoo.com

\begin{abstract}
If power [...] never did anything but say no, do you really think one would be brought to obey it? What makes power good, what makes it accepted, is simply the fact that it doesn't weigh on us as a force that says no, but that it produces and traverses things, it induces pleasure, forms of knowledge, produces discourses. It needs to be considered as a productive network which runs through the whole social body, much more than a negative instance whose focus is repression. (Foucault 1980: 119)
\end{abstract}

(c) BY-Nc-ND 102015 Aaron L. Miller.

This work is licensed under the Creative Commons Attribution-NonCommercial-NoDerivs 3.0 License. 


\section{Introduction: the "monster" of high school baseball}

The 2020 Tokyo Olympics will bring with them two important questions: "How will Japan welcome the global sports world?" and "How should the world understand Japanese sports culture?" As a nation, Japan is struggling to conserve energy in a post-Fukushima world, struggling to remain peaceful with its neighbors as they grow, and struggling to establish a sustainable political identity on a complex world stage. The behavior of and discourses encircling sporting bodies reflect these challenges, and they are shaped by them in turn. Indeed, Japanese sporting bodies will be a focal point as the world and Japan answer these questions.

Japanese society encountered sports rather haphazardly in the Meiji Period, adopted some but not others, and has chosen to develop certain sports but not others since. Baseball is the most noted example - its rise over a century has made it a Japanese national pastime. A recent story from Japanese high school baseball highlights the predicament Japan faces as she prepares to show off her sports culture to the world, and the difficulty people in the West face trying to make sense of it. In 2013, Tomohiro Anraku, a 16-year-old pitcher from Saibi High School (Matsuyama), tossed an incredible 772 pitches in one national high school baseball tournament. Anraku had been groomed for the tournament, which is played at Koshien Stadium near Kobe, by his parents, who had met as concession workers at Koshien Stadium and started him playing the game at the age of three, and by his coach, Masanori Joko, who believed that his players should honor their field as if it were as holy as a temple floor. Over night, Anraku's example of endurance thrust him into the national spotlight, and people in and out of Japan admirably labeled him kaibutsu ('monster').

Yet Anraku's high pitch count also brought calls of coaching "abuse," and Western reporters questioned the dangers of Japanese sports culture (Passan 2013). Why did Anraku accept such a monumental physical challenge? Was his coach culpable of forcing him to sacrifice his body for the sake of the team? Was this simply an example of a sports culture that was "disabling" its members (McDermott and Varenne 1995)? Newspaper reports after the tournament suggested that the decision to stay in the game was Anraku's idea, and that his coach had simply let him have his way, so how can we understand this young man's questionable decision?

In this paper, I will show why Anraku's story, while hardly exceptional within Japanese sports, cries out for a new understanding of power and the body in Japan. The French historian and social theorist Michel Foucault had little to say about sport, and even less about Japan, but he changed the way social scientists 
understand power and the body, and from his writings we can infer a Foucauldian theory of the Japanese sporting body.

\section{Foucauldian theory and the Japanese sporting body}

Applying Foucault's work, especially his ideas of "power relations" and "biopower," can help us to better understand perceptions of the Japanese sporting body. Foucault insisted that we "historicize" social phenomena in order to examine the nature of power and social change on a deeper level. He was skeptical of conventional definitions of "power," insisting that he did not study "power" per se; rather, he studied the history of "how humans were made into subjects," or, in another articulation, how a new "economy of power relations" was necessary (Foucault 1982: 219). This “economy," he believed, needed to start not from a study of those "in power," but those in resistance to it. To Foucault, such "power relations" were characterized by the "governing" and "structuring" of the "possible field of action of others"; in other words, controlling the possible actions that one could or could not take (Foucault 1982: 221). Such a conceptualization of power relations supposed that people being subjected to power were free and not slaves, and that each individual was "thoroughly recognized and maintained to the very end as a person" (Foucault 1982: 220). It also meant that subjects were free to decide for themselves whether or not they wanted to do what power demanded. Thus, in some cases, those "in power" did not need to take any action to keep their subjects in line, because subjects would willingly toe the line without coercion. Indeed, coercion was not a key component to Foucault's concept of power.

Foucault calls this the "productive nature of power." "Power" routinizes behavior and shapes consciousness regarding what forms of behavior are acceptable or unacceptable, thereby "producing" certain discourses and forms of knowledge. For Foucault, power relations do not necessarily repressively control bodies, as Marx would have predicted. In that sense, Foucault's theory perhaps better helps us to understand how Japanese sporting bodies have been "made." The concept of "bio-power" further clarifies his argument. "Bio-power" represents one of three ways that Foucault believed humans are made into "subjects." The first way is by "dividing practices," in which people are separated into categories (e.g., separating the sane from the insane by putting the latter in mental hospitals). The second way is by objectifying people as subjects in a process called "scientific classification," which is a process that often involves 
the physical appearance of the human body. Finally, for Foucault people are made into subjects by their own "subjectification" of themselves (Rabinow 1984: 7-11). This is "bio-power": people apply "technologies of power" upon themselves that "power" would have applied had they not done so. This further explains how power produces, rather than only represses, behavior and discourse. The body is thus a key part of this equation. "Bio-power" creates a mechanism that routinizes physical behavior as people who are "not in positions of power" begin to adapt their behavior and move their bodies in line with what those "in power" would want. Foucault's theories of "power relations" and "bio-power" illustrate how, through sport, Japanese bodies have been made into "subjects."

Anraku's overworked arm is an example of Foucauldian power relations and bio-power in action, at least in the sense that popular discourses of proper Japanese sporting behavior were pervasive enough to convince this 16-year-old boy to carry on in the way he did, even if it meant risking bodily injury. Earning the pride of his family, coaches, teammates, hometown, and even nation must have been on Anraku's mind during those Koshien games. The possibilities of becoming known as a "power pitcher," of becoming a professional ballplayer in Japan, and perhaps even of becoming a "big leaguer” in America, were probably on Anraku's mind, too. Koshien was a stage upon which Anraku could showcase his talent, effort, and abilities for the world to see. He would have let everyone down if he had asked his coach for a relief pitcher, and he might have made people question his ability to endure pain, sacrifice himself for the team, and never give up. In short, stepping off that pitcher's mound might have caused some people to question his very Japaneseness. Anraku faced not only fierce opposing batters in that Koshien tournament, but also powerful rhetoric about how Japanese sporting bodies must overcome their "inherent physical weaknesses" by giving one's all, at any cost.

This paper begins with a two-part theory of how we can best understand "Japanese sports," before moving on to a discussion regarding Japanese body movement. Here I first focus on dissonance during the Meiji Period regarding the way the body was viewed, ${ }^{1}$ and then I show how Japanese bodies were exploited through militaristic physical education training prior to and during WWII. Finally, I turn my attention to the 1964 Tokyo Olympics, when Japanese

1 I use the Meiji Restoration (1868) as the starting date of this transition, although the first arrival of the Black Ships (kurofune) or the first enactment of laws regarding physical education by the Meiji Japanese government could also be used. In any case, this rapid period of transition in the late nineteenth century brought about fundamental changes in the way that Japanese people perceived their own bodies in sport and society. 
on a broad, national scale began to see their bodies as "physically inferior" or "lacking the power" of Western sporting bodies.

It was at this juncture, I argue, that the perception that Japanese sporting bodies "lack power" and are "physically inferior" converges with the belief that Japanese people have a fundamentally different and "unique" philosophy regarding the body, creating a powerful discourse that shapes today's Japanese body consciousness. This sense of inferiority and uniqueness persists, probably because Japanese see international sports events as one of only a few available proxies for international competition. Why? By the terms of its surrender in 1945 and by Article 9 of its postwar constitution, the Japanese nation has been restricted from waging war or maintaining a standing army, and must therefore rely on the United States for military defense. ${ }^{2}$ Asserting their physical cultural uniqueness in sports helps Japanese people to cope with a sense of physical inferiority that is rooted deep in their national history.

Foucauldian theory predicts the emergence of such nationalistic and triumphalist discourses in sport, irrespective of whether they are distorted or psychologically damaging to the people who are exposed to them. Indeed, Foucault's theory places great emphasis on the power of discourses, because they shape our consciousness even if that consciousness may be warped or unfair. Everybody who is disciplined under such unbalanced "power relations" is subject to the Foucauldian mechanism of "bio-power."

These power relations produce certain behaviors. Since many Japanese believe that their sporting bodies are inferior, they also often believe that they must follow methods of sports practice that can overcome their relative physical "weaknesses." Foucault's theory of power relations explains why certain sports institutions within Japanese society, such as the Japan Sports Association or the Japan Basketball Association, insist that Japanese must imagine their own unique forms of sports training in order to overcome this sense of inferiority, and possibly win more international competitions. These perceived hierarchies of body size and strength have become so ingrained in people's minds, so "normalized" that they drive Japanese athletes and coaches to carefully select certain methods. However, while Foucault's theory explains the ideology of inferiority, there is no empirical proof. In fact, this ideology is widely based on quantitative definitions of failure in games that have rather arbitrarily conceived rules. Most Olympic sports, too, have their origins in the West and therefore privilege certain body movements over others. Only recently have there been attempts to add more Eastern sports,

2 It should be noted that at the time of writing, a revision of Article 9 that would allow the use of force for the purpose of self-defense is being discussed. 
such as judo, to the menu of Olympic sports, in an effort to counterbalance today's disproportionate emphasis on Western sports.

In all modern societies, sports are key institutions, through which "appropriate" body behaviors and "truths" about the body are normalized (Mauss 1934). The Japanese sporting body is therefore a core site for the construction of the Japanese national identity. In the world of international sport that often means the incorporation of an "inferior" physical consciousness, which can only be overcome with the proper application of indigenously Japanese training practices. The assumption underlying this consciousness is that Japanese sportsmen and sportswomen can best play and perform together, if they also stick and train together.

\section{Understanding Japanese sports}

\subsection{Japanese sports as physical culture}

Many scholars are beginning to turn their attention to sports as fascinating realms of sociocultural life (Kelly 2007: 1). These scholars are trained in various disciplines in the social sciences and humanities and have overcome the narrow understanding of modern sports as the antithesis of old forms of body movement, such as dance or religious ritual. Modern sports today are characterized by secularism, equality, bureaucratization, specialization, rationalization, quantification, and the obsession with records (Guttman 2004 [1983]; Guttman and Thompson 2001: 3). However, contemporary sports studies around the world have expanded their scope and included many new aspects, such as the body, education, gender, race, and power. As a subject of academic inquiry, the body has increasingly challenged scholars of sport, physical education, and the martial arts in the East (Brownell 1995; Sugimoto 1995; Horne 2000; Noguchi 2004; Kelly 2007; Otomo 2007). Many scholars of Japanese sport have also taken a closer look at the "physical culture" or "body culture" of Japan (Sugimoto 1995; Ben-Ari 1997; Horne 2000; Spielvogel 2003; McDonald and Hallinan 2005: 198; Kelly and Sugimoto 2007; Kelly 2007; Light 2008).

How can we best understand Japan's sports culture? Is it indeed a "body culture," or is it something more? A major premise lurking behind many writings on "Japanese physical cultural activities" - that is, martial arts, physical education, and "Western" sports - has been that there is something unique about the Japanese body and Japan's physical culture (Nakamura 1981, 2002; Otsuki 1989, Otsuki 2002; Murasaki 2002; Ozawa 2002; Kuraishi 2005; Hayashi 
and Kuzuoka 2004; Noguchi 2004). Many authors assume that the ways in which Japanese people move their bodies in these physical cultural activities are “uniquely Japanese.” However, as Kelly (2007: 13) duly notes, the problem with this logic is that it is difficult to reconcile the sleek and well-trained physiques found in Tokyo fitness clubs (Spielvogel 2003) with the corpulent bodies of Japan's sumo wrestlers (Whang 2007). Can either of these bodies represent "the" Japanese sporting body? Given the rather different expectations of the bodies of athletes in these physical cultural activities, how can one assume a single, national physical culture of Japan? We must therefore unpack the meanings of Japanese sports and the Japanese sporting body.

According to Sugimoto (1995: 156), people in Japan began to see their sports as part of their own "physical culture" (shintai bunka) in the 1980s. When sports (supōtsu) were first introduced to Japan in the Meiji Period, they were widely considered as modern and Western entities. At that time, Japanese did not really understand the idea that a "competition" could be "played." In fact, even the word for "competition" (kyōgi) had to be created (Collins 2007: 7). In the decades that followed, Japan began to realize that sports were not simply diversionary pursuits or competitions, but powerful ways to integrate with the international community, especially through the Olympic movement. Slowly, sports began to offer Japanese an opportunity to demonstrate their strengths to the world. At the same time, Western sports were gradually incorporated into the Japanese society, a process that was inherently tied to the nation's desire to be accepted as a modern state and as a unique culture at the same time. The sporting body was key to this process.

Sports as an integral part of Japan's physical culture and "physical cultural activities" deserve serious scholarly attention. Much of the aforementioned scholarship implores us to analyze the human body and its relationship to sport, to consider its role in fostering power or gender hierarchies, to explore the connection between media representations and the formation of these ideal types, and to scrutinize why the body is often perceived as a unique "ethnic entity" in an international and comparative context. There is a great need to understand the historical and contemporary contexts in which statements regarding the sporting body emerge, especially those that purport to explain its uniqueness or superiority.

\subsection{Japanese sports as education}

Sports in Japan as physical cultural activities must be understood within the context of the country's changing global role and identity. Domestically, 
however, they are also important educational tools. A recent memo published by Japan's Ministry of Education, Culture, Sports, Science and Technology (MEXT) succinctly summarizes this point:

Sports are valuable culture that we the human species have created; culture that is based upon the enjoyment of spontaneous exercise and does not discriminate on the basis of gender, age, or physical ability; culture in which humans can share the joy and passion of movement while also deepening social ties. Moreover, sports develop character, foster respect for discipline and justice, produce a collaborative spirit and friendliness toward others, and cultivate a sense of vigor in our youth. These youth will support our nation in the next generation. (MEXT 2013: 2)

Of course, the idea that sports and physical education could "cultivate and discipline" is not new. Roden's (1980) study of athleticism among elite students at Tokyo's First Higher School during Japan's imperial days demonstrates just how influential it was through history. Many fathers of Japanese sport, from Suishū Tobita (1886-1965) in baseball to Jigoro Kano (1860-1938) in judo, also noted the character-building value of sport (Blackwood 2008). Today, school education in Japan continues to incorporate body movement in several ways: with formal "physical education" (taiiku) classes, with elective "extracurricular clubs" (bukatsudō), and with school events such as the "sports festival" (undōkai). The idea of taiiku, which became the preferred term of the Japanese government after WWII, implies the "nourishment of the body." It was derived from the German term körperliche Erziehung and originally based on the philosophy of Herbert Spencer (1820-1903) to educate mind, body, and soul. Many bukatsudō are sports clubs, though there are other club options including art and music. From the late 1970s to 2002, there were also nonmandatory "club activities" (kurabu katsudō). As Mizuo, Ikai, and Ebashi (1973: 228) note, kurabu katsudō were meant for the students to "have fun once per week," quite in contrast to the bukatsudō, which were serious physical trainings endeavors for mastery.

Due to a rather intimate historical association with taiiku in Japan, supōtsu have often been explicitly associated with the formal education system (Guttman and Thompson 2001: 90). As in many nations with national, centralized education systems, the Japanese education system today plays a significant role in creating a dominant image of what the Japanese sporting body should look like, and education and sport have been close cousins throughout modern Japanese history (Miller 2011). This means that imaginations of the Japanese sporting body are often imaginations about the best way to build strong and able bodies through formal, standardized education. Today, Japanese define sports as physical cultural activities that have once been inherently "Western," but which are also malleable entities that have been integrated and localized successfully, 
endeavors they have learned to play and coach in their own, culturally specific way. This "Japaneseness" of Japanese sports culture is enculturated and normalized through the national education system. Cultural and educational evaluations of sports are thus essential to our understanding of how sport has shaped the historical and contemporary discourses of the Japanese sporting body.

\section{Understanding the Japanese sporting body}

\subsection{The sporting body as a cultural hybrid}

Current views of the Japanese sporting body have emerged from historical interplay between powerful and influential institutions (Kelly 1998: 103; Horne 2000: 83). These include the state, the military, the education system, business groups, and advocates of science and medicine. In order to fully understand today's perceptions of the Japanese sporting body, we must flesh out how these institutions have sought to establish their vision(s) of what the Japanese (body) should be. Japan's encounter with modern, Western sports, which began in the Meiji Period and continues today, oscillates between the acceptance of physical, educational, and cultural ideas and techniques from the West and their adaptation into a culture-bound Japanese context. This "negotiation process" is evident through Japanese sports history and has created a hybrid physioeducational sports culture.

In the Meiji Period, Japanese society perceived sports as Western entities and attempted to localize them (Abe 2006). Even during this process of localization, the conflict between the new Western sports culture and old Japanese physical culture, often associated with martial arts (budō), continued. Western sports were seen as inferior to indigenously Japanese physical cultural activities. One Meiji Period writer averred: "Japanese bujutsu [martial arts] is our original exercise, which, down the ages, has ensured numerous feats, rendered good service to the state, and inspired the people" (quoted in Abe and Mangan 2002: 107). Consequently, when Western sports were introduced, people initially denigrated them as "foreign" and demanded their "Japanization."

At the same time, there were concerns that the distinctly Japanese notions of the body might be undermined or even destroyed in the process of Westernization. Noguchi (2004: 8) emphasizes the "unique" notions of kata (form), waza (skill), and shugyō (ascetic practice). He argues that these specifically Japanese ideas of body movement became biased toward the West after the Meiji Restoration, because the introduction of a modern system of physical education "dismantled 
traditional ways of moving the body" (Noguchi 2004: 11). The ascetic practices of Shinto and Zen Buddhism, too, influenced Japanese ideas of the body significantly. Noguchi explains the notion of gyō (which can loosely be translated as "practice" and represents the second character in the compound term shugyō) and its relationship to kata, in the following way:

The practice of Gyo [broke] out beyond the field of religion to become the foundation for a certain view of the body, and would further give birth to the concept of Kata, or form. Kata is the symbolic expression of the Japanese view on the body, born from Gyo. The Japanese reverence for Gyo would eventually shift into a sense of respect for Kata. (Noguchi 2004: 20)

Kata is seen here as an essential term to understand ideas of the Japanese sporting body. Indeed, for Noguchi, kata forms an indispensable foundation for Japanese culture itself:

This philosophy of Kata was a system of techniques for using the body that comprehensively involved the Japanese view of the body, their perceptual inclinations, and the distinct ways in which they used their bodies. This system [...] became the foundation for Japanese culture. It cultivated the grounds for the blooming of Waza or skills in all fields, and was the driving force for the assimilation of Chinese civilization into the land of Japan. This system of bodily skills, which existed beneath and throughout all aspects of Japan's culture, differed entirely from the Western idea of the body that was disseminated by the government and blindly accepted by the general population after the Meiji Restoration. (Noguchi 2004: 23)

Whether or not one agrees with Noguchi's assertion that traditional Japanese body culture was "destroyed" by Japan's encounter with the West, it is fair to say that the education system has been a key conduit through which ideas of the Japanese sporting body have been disseminated, challenged, or changed. Various historical traditions, religions, or ways of thinking ( $k a t a$, waza, shugyō, Zen, Shinto, and Confucianism) have obviously influenced contemporary ideas of the Japanese sporting body, but Japan's encounter with Western sports and their modern concepts of the body raised a fundamental question: How would the Japanese body move in the twentieth and twenty-first centuries? In a traditionally Japanese way? Or in a Western way?

\subsection{Training for war: the sporting body as an agent of militarism}

In the course of the Meiji Restoration, Japanese authorities began to use physical education to prepare bodies to defend the nation. In the age of imperialism and colonialism, governments around the world used schools to train soldiers, and 
Japan saw no reason to buck the trend. In 1885, military exercises (heishiki taisō) were introduced to the Japanese school under the School Education Law (gakkō rei), and "school education came to gradually become a space for creating a new body fit for the military” (Yoshida 2002: 54). The rapid and successful industrialization triggered economic growth, as well as political expansion. Japan's victory in the Russo-Japanese War (1904-1905) further fueled its militarization, and military authorities saw physical education and sport as powerful tools of war training. In the 1920s, a Physical Education and Sports Bureau was established within the Ministry of Education (McVeigh 1998: 143-144), and from 1925, military officers were sent to special schools to ensure proper physical education and tough military training (Horne 2000: 79). In 1931, Japan invaded Manchuria, and the Japanese government made the practice of the martial arts and bushido ('the way of the warrior') compulsory within the school system (Collins 2007: 12). Bushido was thereafter used unapologetically to fuel nationalism and to persuade Japanese citizens that there was value and dignity in the pursuits of the imperial nation. The bushido spirit was thus appropriated - and arguably corrupted - in this warring period under the guise of physical education.

Frost (2008) has told the tragic story of baseball star Eiji Sawamura, a Japanese sportsman and war hero. He had become popular as "the man who struck out Babe Ruth" during an American all-star team's trip to Japan in the late 1920s, but was killed in WWII, when his submarine sunk. Sawamura was considered a role model when he entered the military, because his years as a baseball player had crafted his body with great physical strength. In his diaries, he explained that, having thrown so many baseballs in his life, he could throw grenades farther than any other soldier. He apparently enjoyed military service, too, imagining it to be "fun," and became an influential proponent of the war. He related his "hard" athletic training to his "hard" military training. Both pursuits, Sawamura insisted, needed a "big body," and as a soldier he believed what the militarists controlling the Japanese government reiterated: that sports training could serve as great preparation for more than just games (Frost 2008: 14-15, 17).

\subsection{The Tokyo Olympics and the spreading sense of physical inferiority}

Although Japan successfully adopted and adapted Western ideas, systems, technologies, and political strategies at an unprecedentedly rapid pace, the victories over China and Russia and the colonization of Asia (Korea, Taiwan, Singapore, China) were rendered meaningless through the defeat to the Allied Powers in August 1945. In the surrender, Japan realized that the imperial political 
project had failed, and that she had to clarify her future role in the world. This open question included the new shape and purpose of physical education and sports in postwar Japan.

The staging of the Olympic Games in Tokyo in 1964 was a significant turning point on Japan's road to economic recovery. Together with the Shinkansen (bullet train), they highlighted a period of growth transforming Japanese society. For the first time, groups of larger and taller Western athletes visited Japan for the Olympics and demonstrated firsthand to the public that the Japanese sporting body was, in comparison, rather slight in stature (Oki 2001: 10). The 1964 Olympics inscribed this feeling of inferiority into the Japanese self-perception in sport. The image of the supposedly inferior body size transpires in many popular and even academic publications. For example, Funakawa (1968) explores the Japanese body by comparing it to the bodies of other nationalities or regions, such as Denmark and Africa. In one chapter entitled tairyoku ('body strength'), he compares the average heights and weights of Japanese and German athletes, finding that Japanese men in track and field weighed less and stood shorter (65.4 $\mathrm{kg}, 172.1 \mathrm{~cm})$ than Germans in the same sport $(76.1 \mathrm{~kg}, 180.9 \mathrm{~cm})$. For Japanese women's track and field athletes, the gap was even greater $(55.3 \mathrm{~kg}, 160.3 \mathrm{~cm}$ to Germany's $68.0 \mathrm{~kg}, 172.5 \mathrm{~cm}$ ) (Funakawa 1968: 284).

Although a sense of physical inferiority had probably existed already since Japan's re-opening to the West in the 1860s, and although we know that "athleticism and sports were promulgated as official national concerns after Japan's dismal performance in the 1912 Olympics” (Collins 2007: 9), it was these Olympics on home soil in 1964 that convinced a majority of the Japanese population that the Japanese sporting body was "physically inferior" and perhaps even "less desirable" (Horne 2000: 75). The Tokyo Olympics spread a discourse of "inferiority" throughout the nation, and sports rhetoric, practice, and policy began to reflect the "necessity" of keeping up with the bigger bodied, more athletic (Western) Joneses.

\subsection{Theories of mind and body: scholarly assumptions of cultural difference}

Curiously, some Japanese scholars have embraced this supposed "fact" of "physical inferiority" in order to make the case that Japanese athletes can be "superior" to Western athletes, if they train "properly." Key to this claim is the assumption that body and mind are not separate, but one entity. Japanese 
sports scholars like Toshio Nakamura and Osamu Kuraishi oversimplify their comparative analysis of sport by claiming that all Westerners follow a Cartesian mind-body split. According to Kuraishi, "mental training" is important in the West, because mind and body are considered separate. In contrast, people in Japan believe that "training the mind goes hand in hand with skills training," a "fact" that is expressed by the "trinity (sanmi ittai) of spirit, skill and body (shingitai)" (Kuraishi 2005: 44). In this regard, Kuraishi confirms Nakamura (2002), who wrote that Japanese athletes follow a philosophy of "body and mind as one" (shinshin ichigenron), whereas those in the West follow a philosophy of "body and mind as two" (shinshin nigenron).

These scholars argue that Japan is "unique" for believing in this inseparability of body and mind, but they are simply imagining the "other" in order to construct an ideal "self." This is clearly a straw-man assumption used to support a convenient assumption: while Westerners believe that mind and body are two separate entities, Japanese athletes can only succeed if they accept their inseparability and train them in tandem. In fact, as Spinoza's seventeenth-century rejection of the Cartesian idea of a mind-body split indicates, there is no blanket following of this principle in Western philosophical history, let alone in Western sports or society today (Della Rocca 1996; Miller 2013: 146-148). Training in sports and the martial arts have long been discussed as having the ability to provide harmony between body, spirit, soul, and mind, not only in Japan. In ancient Greece, for example, Socrates argued that "the ideal of Western education," i.e., the training of mind and body, was the integration of the body and the mind into the service of the soul.

Such straw-man arguments seem especially ironic if one considers that Englishman F. W. Strange was one who introduced and taught many sports to Japan in the Meiji Period. Strange drew on ideas from ancient Greece, when he emphasized the importance of sport by linking active exercise with good health and improved mental strength. All this shows that the idea of the inseparability of body and mind had (also) been brought to Japan by a Westerner and could not be inherently Japanese (Abe and Mangan 2002: 101). One cannot generalize the belief of all Westerners regarding mind and body, nor the thinking of all Japanese. There are clearly sporting spaces within Japanese society that do not fit into the constructed categories of shinshin ichigenron (Japan) or shinshin nigenron (West). In her work on Japanese fitness clubs, for example, Spielvogel argues that neither mind-body split nor mind-body synthesis completely describes the views of people in her field of study, and that there are more subtle and sophisticated ideas about the body fluctuating behind the mask of the mind-body dichotomy (Spielvogel 2003: 25-26, 210). 


\subsection{The underdog view from the field}

Apart from the scholarly debate about the Japanese sporting body, Japanese athletes, too, contribute to the discourse with statements about their bodies, mostly about their physical inferiority in international competitions and professional sports leagues. One example is the Japanese baseball player Hideki Matsui. The relatively large (6'2", 210 lbs) slugger of the Tokyo Giants and the New York Yankees was like Anraku called a "monster" "and "Godzilla”" in his youth because of his extraordinary size and strength. But even Matsui shows a sense of physical inferiority, when he writes: "I'll probably never be able to hit as many home runs as Major League Baseball (MLB) home run hitters because their bodies [...] are different from mine" (Matsui 2007: 108). Matsui towered over some American peers while he played in the MLB, but his overall view was that his body was less suitable to being a "power hitter" than that of an American.

In "ball sports" like baseball, basketball, and volleyball, physical size probably matters more than in "non-ball sports" like swimming or long-distance running. Katsuta (2002:135) explains: "We have come to expect to see American professional basketball and professional baseball players, who have much larger builds (ogara) than Japanese athletes and perform splendidly and with more agility (shunbin) than Japanese athletes." Similarly, in a women's volleyball competition against China on 12 July 2008, the announcers for Japan's public broadcaster NHK stated unhappily that the Chinese athletes' bodies were "huge" (dekai). In sports like basketball, in which height is considered a key factor of success, the relatively small Japanese body is often seen as a liability that must be overcome by simultaneous training of body and mind. Former Japan Basketball Association (JBA) Chairman Isao Kaneko reiterates that "the gap between Japan and the strong basketball nations as well as between the Asian rivals is widening," and that in order to bridge this gap, "we have to create an 'original Japan [style] basketball”" (JBA 2004: 1). This "Japan [style] original basketball,” according to the JBA, is "basketball which, flatly, rationally and at a high pace, makes the most of the distinctive speed, agility and running ability of Japanese [athletes]" (JBA 2004: 12). For the JBA, a "distinctly Japanese style of basketball” is necessary to overcome the "inferiority" of the Japanese basketball body.

Perhaps Japanese athletes see themselves as "physically inferior" because sports are ultimately competitions of skill, size, and speed, and therefore highly dependent on physical contingencies. But many sports were also conceived as part of what I call a triumphalist and nationalistic paradigm, which generally dignifies the countable successes: weights, heights, speeds, points, medals, and victories, to measure and compare values. Most sports are thus "zero-sum competitions," in which by definition only one team or individual can win and 
the other must lose. In this realm, the numbers are said to "never lie.” Moreover, since both body size and scoreboard results are equally visible to common fans, the public, and the media, they often assume a causal link between body size and athletic success - irrespective of the fact that quantified measurements often ignore non-quantifiable factors like enjoyment, spirit, and team camaraderie, which are also core elements of these physical cultural activities.

The idea of the "underdog" could not exist without this emphasis on the quantifiable and the measurable. When the smaller dog wins, it raises eyebrows because it seems to defy the laws of nature. Japanese athletes and coaches seem to enjoy playing the part of the underdog, and the narrative of physical inferiority supports the notion of Japanese sports "lagging behind": with the body size of its athletes, with the number of victories at international competitions, and with its status as a nation or race (Spielvogel 2003: 2).

\section{Conclusion}

Not all Japanese athletes have a sense of physical inferiority, of course, nor do all Japanese coaches think uncritically about what body size means, or believe that big bodies always perform better. When I conducted interviews at a coach certification event of the Japan Sport Association (JASA), coaches told me that in certain sports (e.g., table tennis), big bodies were "actually useless," because they use excess energy to perform motions that a smaller body can do more easily and rapidly. In these discussions, which often included the recently completed 2008 Olympic Games in Beijing, coaches explained that the "Asian body" could actually be viewed as "superior" in such sports, and also noted that China had won the most gold medals (51) that summer - the first time for an Asian nation.

Similarly, baseball stars like Matsui acknowledge that Japanese bodies and the bodies of other East Asian baseball players are unique in that they have "pliancy/flexibility" (shinayakasa), and that hitters can "shorten their swings" to make up for a lack of body size (Matsui 2007: 77, 108). Indeed, although Matsui's statements about his body's smaller size suggests that even the strongest Japanese athletes occasionally buy into Japan's rhetoric of physical inferiority, he also insists he is not "jealous" of MLB players and their larger bodies. Likewise, Japanese sports scholars like Oki (2001: 58) acknowledge that while "in almost all sports size is an advantage [...] one cannot say that size alone will bring success or that the short are inferior." He confirms how important it is in a competition for smaller players not to believe in their inferiority. 
So why then do so many Japanese athletes still hold on to the relationship between body size and success? Why does the perception of the Japanese body as inferior to the Western body persist in many sports? One answer is that this stereotypical assumption also offers a cultural or political advantage. The maintenance of a sense of national inferiority helps to support a strong sense of national identity. Scholars like Noguchi, Nakamura, and Kuraishi seek to emphasize the cultural differences between the ways Westerners and Japanese approach the training of the body and mind, in order to highlight the uniqueness of Japanese sports culture. These scholars see value in widening cultural differences, because that allows for a clear definition of Japanese sports culture and a strong national identity.

This thinking fits precisely into Foucault's idea of power relations. They produce certain forms of knowledge: that the Japanese sporting bodies are unique (if "inferior"), and incentivize certain behaviors: the indigenously designed training regimes to maximize the potential of national uniqueness and to overcome the supposed Japanese "inferiority." Foucauldian power relations "produce" the idea that Japanese basketball players must capitalize on their speed in order to overcome their limited body size and win internationally. Thus Foucauldian theory helps us to understand why, during Japan's rise in the late nineteenth and early twentieth century, the Japanese believed that her sporting bodies were inferior, and why this idea was bolstered by firsthand observations of the larger sizes of non-Japanese sporting bodies at the 1964 Tokyo Olympics. It also helps us understand why these perceptions persist. After all, Japan is still living in the shadow of a greater military and sporting power, the United States. Quite in contrast to Japan's economic success, the power imbalance in international power relations continues, both in the political arena and in the stadium. As a result, discourses of physical inferiority - and the need to collaborate to overcome them - continue to echo.

Ironically, Japanese sports today fulfill the same function for the modern national state which the martial arts fulfilled in feudal Japan. As we have seen, in the Meiji Period martial arts were considered powerful and indigenous entities serving the state and nation. When Western sports were introduced, people initially labeled them as "foreign" and insisted on their "Japanization." Now that this process of adaption has been completed, sports competitions in Japan shape and foster a consciousness of nationalism - exactly like in the West. International sports events, above all the Olympic Games and the World Cups, sell themselves as festivals beyond politics and outside international power relations. But they are not. They too shape people's consciousness, compare athletes and performances, celebrate winners and victories, and confirm stereotypes of the team, or group, or nation. 
The notion that the Japanese sporting body is "physically inferior," however widely it may be accepted, rests on shaky grounds. It constructs and projects a simplistic, monolithic notion of "the West" and its sporting body. Both are unfounded straw men. This notion of Japanese "physical inferiority" also ignores the particular historical circumstances of Japan's adoption of Western sports and games, turns a blind eye to their evolution within its culture and education system, refuses to think beyond the dichotomy of "West as mind-body split" and "Japan as mind-body monism," and ignores Japanese athletes whose body sizes and beliefs do not fit into the generalization. The persistence of this notion, no matter how logically flawed it may be, shows just how powerful the Foucauldian mechanisms of "power relations" and "bio-power" are in shaping a nationalistic, triumphalist consciousness through the sporting body, and how thoroughly this consciousness can trickle down to all levels of Japanese sports, even to 16-yearold baseball players like Tomohiro Anraku.

\section{References}

Abe, Ikuo. 2006. Muscular Christianity in Japan: The growth of a hybrid. International Journal of the History of Sport 23(5). 714-738.

Abe, Ikuo \& J. A. Mangan. 2002. Sportsmanship - English inspiration and Japanese response: F. W. Strange and Chiyosaburo Takeda. International Journal of the History of Sport 19(2). 99-128.

Ben-Ari, Eyal. 1997. Body projects in Japanese childcare: Culture, organization and emotions in a preschool. Richmond: Curzon.

Blackwood, Thomas. 2008. Bushidō baseball? Three "fathers" and the invention of a tradition. Social Science Japan Journal 11(2). 223-240.

Brownell, Susan. 1995. Training the body for China: Sports in the moral order of the People's Republic. Chicago: University of Chicago Press.

Collins, Sandra. 2007. The 1940 Tokyo Games: The missing Olympics. Abingdon: Routledge.

Della Rocca, Michael. 1996. Representation and the mind-body problem in Spinoza. New York: Oxford University Press.

Foucault, Michel. 1980. Power/knowledge. New York: Pantheon Books.

Foucault, Michel. 1982. Afterword: The subject and power. In Hubert Dreyfus \& Paul Rabinow (eds.), Michel Foucault: Beyond structuralism and hermeneutics, 208-226. Chicago: University of Chicago Press.

Frost, Dennis. 2008. Taking one for the team: Sports celebrity in militarized Japan. Paper prepared for the Annual Meeting of the Association of Asian Studies, Baton Rouge, LA.

Funakawa, H. (ed.) 1968. Nihonjin no tairyoku [The body strength of the Japanese]. Kobayashi Shoin.

Guttman, Allen. 2004 [1983]. From ritual to record: The nature of modern sports, 2nd revised edn. New York: Columbia University Press. 
Guttman, Allen \& Lee Thompson. 2001. Japanese sports: A history. Honolulu: University of Hawaii Press.

Hayashi, Shingo \& Motoyasu Kuzuoka. 2004. Yakyūgata vs. sakkāgata: yutakasa e no kyōgibunkaron [Soccer type vs. baseball type: A cultural theory of sport seeking wealth]. Tokyo: Heibonsha.

Horne, John. 2000. Understanding sport and body culture in Japan. Body and Society 6(2). 73-86.

JBA (Japan Basketball Association). 2004. Endeavor Project: Japanese Basketball Association concept book. http://www.japanbasketball.jp/training/all.pdf (accessed 3 September 2014).

Katsuta, Takashi. 2002. Kokusai rūru kaisei ni miru Nihon no kadai [Issues for Japan in the reform of international rules]. In Toshio Nakamura (ed.), Nihonjin to supōtsu no aishō [The chemistry of sports and the Japanese], 117-143. Tokyo: Sōbunkikaku.

Kelly, William W. 1998. Blood and guts in Japanese professional baseball. In Sepp Linhart \& Sabine Frühstück (eds.), The culture of Japan as seen through its leisure, 95-111. New York: State University of New York Press.

Kelly, William W. 2007. Introduction. In William W. Kelly \& Atsuo Sugimoto (eds.), This sporting life: Sports and body culture in modern Japan, 1-24. New Haven: Yale University Council on East Asian Studies.

Kelly, William W. \& Atsuo Sugimoto (eds.) 2007. This sporting life: Sports and body culture in modern Japan. New Haven: Yale University Council on East Asian Studies.

Kuraishi, Osamu. 2005. Basukettobōru no kōchi o hajimeru tame ni [How to start basketball coaching]. Tokyo: Nihon Bunka Shuppan.

Light, Richard. 2008. Learning masculinities in a Japanese high school rugby club. Sport, Education and Society 13(2). 163-179.

Matsui, Hideki. 2007. Fudōshin [Unshakable]. Tokyo: Shinchōsha.

Mauss, Marcel. 1934. Les techniques du corps [The techniques of the body]. Journal de Psychologie 32(1). 3-4.

McDermott, Ray \& Herve Varenne. 1995. Culture as disability. Anthropology \& Education Quarterly 26(3). 324-348.

McDonald, Brent \& Chris Hallinan. 2005. Seishin habitus: Spiritual capital and Japanese rowing. International Review for the Sociology of Sport 40(2). 187-200.

McVeigh, Brian J. 1998. The nature of the Japanese state: Rationality and rituality. London \& New York: Routledge.

MEXT (Ministry of Education, Culture, Sports, Science and Technology). 2013. Undō bukatsudō no arikata ni kan suru chōsa kenkyū hōkokusho [Report from survey research regarding the activity of sports]. http://www.mext.go.jp/a_menu/sports/jyujitsu/_icsFiles/ afieldfile/2013/05/27/1335529_1.pdf (accessed 30 August 2014).

Miller, Aaron L. 2011. From bushido to science: A new pedagogy of Japanese sports coaching. Japan Forum 23(3). 385-406.

Miller, Aaron L. 2013. Discourses of discipline: An anthropology of corporal punishment in Japan's schools and sports. Berkeley: Institute of East Asian Studies.

Mizuo, Tadafumi, Michio Ikai \& Shinshiro Ebashi. 1973. Taiiku kyōiku no genri [Principles of physical education]. Tokyo: Tokyo University Press.

Murasaki, Nao. 2002. Samurai: Sekai no jōshiki o kutsugaesu Nihonjin asurīto no karada kankaku [Samurai: Japanese athletes' body sense overthrowing the common sense of the world]. Tokyo: Gentosha. 
Nakamura, Toshio. 1981. Supōtsu no fūdo [The spiritual features of sports]. Tokyo: Taishūkan. Nakamura, Toshio (ed.). 2002. Nihonjin to supōtsu no aishō [The chemistry of sports and the Japanese]. Tokyo: Sōbunkikaku.

Noguchi, Hiroyuki. 2004. The idea of the body in Japanese culture and its dismantlement. International Journal of Sport and Health Science 2(1). 8-24.

Oki, Masahiro. 2001. Katsu tame no kantokujutsu: Dakara taibatsu wa hitsuyō da [Coaching techniques for winning: That's why corporal punishment is necessary]. Tokyo: Bungeisha.

Otomo, Rio. 2007. Narratives, the body, and the 1964 Tokyo Olympics. Asian Studies Review 31(2). 117-132.

Otsuki, Tatsuyuki. 1989. Te no Nihonjin, ashi no seiyōjin [The hands of Japanese, the feet of Westerners]. Tokyo: Tokuma Shoten.

Otsuki, Tatsuyuki. 2002. Nihonjin to seiyōjin no undōkan to supōtsu [Sports and perspectives on exercise by Westerners and Japanese]. In Toshio Nakamura (ed.), Nihonjin to supōtsu no aishō [The chemistry of sports and the Japanese], 15-46. Tokyo: Sobunkikaku.

Ozawa, Eiji. 2002. Nihonjin no shōhaikan to supōtsu [Sports and the Japanese sense of victory and defeat]. In Toshio Nakamura (ed.), Nihonjin to supōtsu no aishō [The chemistry of sports and the Japanese], 143-166. Tokyo: Sobunkikaku.

Passan, Jeff. 2013. The pitch-count problem: How cultural convictions are ruining Japanese pitchers. Yahoo! Sports. 4 April. http://sports.yahoo.com/news/the-pitch-count-problem-how-cultural-convictions-are-ruining-japanese-pitchers-012016897.html (accessed 20 August 2014).

Rabinow, Paul (ed.). 1984. The Foucault reader. New York: Pantheon Books.

Roden, Donald. 1980. Schooldays in Imperial Japan: A study in the culture of a student elite. Berkeley: University of California Press.

Spielvogel, Laura. 2003. Working out in Japan: Shaping the female body in Tokyo fitness clubs. Durham, NC: Duke University Press.

Sugimoto, Atsuo. 1995. Supōtsu bunka no henyō [Transformations in sports culture]. Kyoto: Sekaishisōsha.

Whang, Soon Hee. 2007. The body as culture: The case of the sumo wrestler. In William W. Kelly \& Atsuo Sugimoto (eds.), This sporting life: Sports and body culture in modern Japan, 193-210. New Haven, CT: Yale University Council on East Asian Studies.

Yoshida, Yutaka. 2002. Nihon no guntai [The Japanese army]. Tokyo: Iwanami Shinsho. 